\title{
Iron Biofortification in Rice: An Update on Quantitative Trait Loci and Candidate Genes
}

\section{B. P. Mallikarjuna Swamy ${ }^{1 *}$, Balram Marathi2*, Ana I. F. Ribeiro-Barros ${ }^{3 *}$, Mark lan C. Calayugan ${ }^{4}$ and Felipe Klein Ricachenevsky ${ }^{5 *}$}

1 International Rice Research Institute, Los Baños, Philippines, ${ }^{2}$ Agricultural College, Warangal, Professor Jayashankar Telangana State Agricultural University, Hyderabad, India, ${ }^{3}$ Forest Research Centre (CEF), Instituto Superior de Agronomia, Universidade de Lisboa, Lisbon, Portugal, ${ }^{4}$ Institute of Crop Science, University of the Philippines Los Baños, Laguna, Philippines, ${ }^{5}$ Departamento de Botânica, Instituto de Biociências, e Programa de Pós-Graduação em Biologia Celular e Molecular, Centro de Biotecnologia, Universidade Federal do Rio Grande do Sul, Porto Alegre, Brazil

Rice is the most versatile model for cereals and also an economically relevant food crop; as a result, it is the most suitable species for molecular characterization of $\mathrm{Fe}$ homeostasis and biofortification. Recently there have been significant efforts to dissect genes and quantitative trait loci (QTL) associated with Fe translocation into rice grains; such information is highly useful for Fe biofortification of cereals but very limited in other species, such as maize (Zea mays) and wheat (Triticum aestivum). Given rice's centrality as a model for Poaceae species, we review the current knowledge on genes playing important roles in Fe transport, accumulation, and distribution in rice grains and QTLs that might explain the variability in Fe concentrations observed in different genotypes. More than $90 \mathrm{Fe}$ QTLs have been identified over the 12 rice chromosomes. From these, 17 were recorded as stable, and 25 harbored Fe-related genes nearby or within the QTL. Among the candidate genes associated with Fe uptake, translocation, and loading into rice grains, we highlight the function of transporters from the YSL and ZIP families; transporters from metal-binding molecules, such as nicotianamine and deoxymugineic acid; vacuolar iron transporters; citrate efflux transporters; and others that were shown to play a role in steps leading to Fe delivery to seeds. Finally, we discuss the application of these QTLs and genes in genomics assisted breeding for fast-tracking Fe biofortification in rice and other cereals in the near future.

Keywords: hidden hunger, biofortification, rice, grain, iron, QTLs, genes

\section{INTRODUCTION}

Hidden hunger affects more than two billion people worldwide and is among the major challenges to be addressed on a priority basis to achieve Zero Hunger, particularly in African, Asian, and Latin-American countries. Indeed, each year there are $c a$. three million deaths due to nutritional deficiencies, mainly proteins, vitamins, and minerals (FAO et al., 2019). Among the 22 essential trace elements, iron $(\mathrm{Fe})$, zinc $(\mathrm{Zn})$, selenium $(\mathrm{Se})$, and iodine (I) deficiencies affect more than half of the world population (World Health Organization, 2002), the first being the most common nutritional disorder (Kennedy et al., 2003; IFPRI, 2015). Fe is crucial for the normal functioning of several biological processes in living organisms (White and Broadley, 2009; Abbaspour et al., 2014; Toxqui and Vaquero, 2015), mainly due to its major role in catalytic activities of many 
enzymes, such as those related to oxygen transport, electron transfer, oxi-reduction reactions, collagen biosynthesis, and vitamin D metabolism (Abbaspour et al., 2014; Toxqui and Vaquero, 2015).

According to the World Health Organization, the prevalence of anemia (insufficient number of red blood cells or oxygencarrying capacity) ranges from $23 \%$ in developed countries to $52 \%$ in the developing world, and half of the cases are derived from Fe deficiency (World Health Organization, 2015). Although Fe deficiency anemia (IDA) affects all population groups, children and pregnant women are the most vulnerable targets (World Health Organization, 2008). Chronic IDA seriously compromises growth and development in children, impairing cognitive and motor development and enhancing susceptibility to infections (Gupta et al., 2016; Wieringa et al., 2016). In adults, anemia affects the immune system and causes fatigue and reduced physical and psychological performance (Failla, 2003; Camaschella, 2017). In any case, the extent of IDA in human health depends on a combined set of environmental, genetic, and physiological factors (Toxqui and Vaquero, 2015; Cappellini et al., 2019). Besides IDA, other types of anemia may be related to (i) active bleeding related to menstruation, wounding, gastrointestinal ulcers, and cancer; (ii) kidney disease related to the decrease in the hormone erythropoietin, involved in the production of red blood cells; (iii) obesity-related systemic inflammation that increases hepcidin, reducing Fe availability; (iv) alcoholism (premature destruction of defective red blood cells); and (v) sickle cell anemia and thalassemia, two genetically inherited diseases related to the abnormal production of hemoglobin (Abbaspour et al., 2014). Additionally, Fe deficiency is also a factor of risk for osteoporosis as it is a key component of enzymes involved in bone metabolism, i.e., biosynthesis of collagen, the main component of connective tissue.

In plants, $\mathrm{Fe}$ is also a crucial constituent of several proteins and enzymes involved in key pathways that sustain plant growth, development, and metabolism, and its deficiency is directly related to the decrease in crop performance (productivity and quality) (Lucena and Hernandez-Apaolaza, 2017; Tripathi et al., 2018). Among others, Fe nutrition has been related to plant tolerance to biotic and abiotic stresses (Aznar et al., 2015; Tripathi et al., 2018; Cesco et al., 2020), being a key element in photosynthesis (Balk and Schaedler, 2014; Krohling et al., 2016), which is affected by different stresses (Munns and Tester, 2008; Chaves et al., 2009). Additionally, due to its low solubility in soils, Fe availability to plants is quite low (Briat et al., 2015). Thus, with the current challenges of agriculture imposed by the current scenario of climate change, population growth, and undernourishment taken together, the development of strategies that allow the improvement of Fe concentration in crops is mandatory to achieve food and nutritional security.

Mineral supplements, food fortification, and crop biofortification are the three strategies that can be used to fight malnutrition. However, implementation of the first two strategies is complex and almost unaffordable in developing and less developed countries; the third strategy constitutes an effective and durable approach (Gómez-Galera et al., 2010; Murgia et al., 2012; Briat et al., 2015). Manipulation of the microbiome, such as using plant growth-promoting bacteria, holds promise to help improve plant nutrition, but it is still at the beginning regarding nutrient levels in edible seeds (Pii et al., 2016; Scagliola et al., 2021). Biofortification strategies include agronomic practices, breeding, and genetically engineered crops, separately or combined (Gómez-Galera et al., 2010). Although conventional breeding is a long-term strategy and transgenic approaches are controversial, costly, and time-consuming, marker assisted breeding (MAB) seems to be the most straightforward step to improve mineral quality of crops.

In this review, we summarize the current knowledge of quantitative trait loci (QTL) identified in multiple studies using different genotypes and review the known genes associated with Fe delivery and accumulation in rice grains. The combination of both is key to identifying the most likely genes to contribute to fast-track the development of Fe-biofortified crops.

\section{GENES CONTROLLING FE TRANSLOCATION AND LOADING IN SEEDS}

There is considerable interest in producing Fe-biofortified cereals for human consumption, and as a result, there are many research groups focused on understanding $\mathrm{Fe}$ homeostasis and mechanisms controlling Fe translocation and loading into seeds of cereal. Here, we briefly review the genes that are clearly shown to have a role in controlling Fe loading in seeds, whether directly or indirectly (Whitt et al., 2020). Other genes that have known functions and were used to generate transgenic, biofortified plants are not included (for a review, see Connorton and Balk, 2019).

Fe is translocated to seeds from two sources: directly from the soil solution through root uptake and remobilization from different tissues and organs during seed development (Sperotto, 2013; Che et al., 2019). Most of our knowledge about Fe homeostasis is focused on Fe transporters involved in root uptake/root radial movement and transcriptional regulators, whereas $\mathrm{Fe}$ homeostasis in shoots and seeds is less understood.

Plants from the Poaceae family use a chelation-based strategy for Fe acquisition, also called Strategy II. For that, phytosiderophores (PS-2'-deoximugineic acid, or DMA, is common in grasses) are secreted to the rhizosphere by major facilitator superfamily transporters (OsTOM1/OsZIFL4 in rice; Nozoye et al., 2011; Ricachenevsky et al., 2011), which chelate $\mathrm{Fe}^{3+}$ and form $\mathrm{Fe}^{3+}$-PS complexes that are transported into root cells by Yellow Stripe-Like (YSL) family transporters (OsYSL15 in rice; Inoue et al., 2009; Lee et al., 2009; Conte and Walker, 2012; Sperotto et al., 2012). Rice also uses $\mathrm{Fe}^{2+}$ transporters (OsIRT1 and OsIRT2) in roots (Ishimaru et al., 2006). NonPoaceae species employ a reduction-based strategy in which $\mathrm{Fe}^{3+}$ is reduced to $\mathrm{Fe}^{2+}$ by ferric-chelate reductase and enters into root cells by IRT/ZIP family transporters (Kobayashi and Nishizawa, 2012). Rice uses a combined strategy for Fe uptake, a trait that was recently shown to have evolved before the domestication of cultivated rice (Wairich et al., 2019). Evidence also points to other 
possible mixed mechanisms of Fe acquisition in eudicots (Xiong et al., 2013; Grillet and Schmidt, 2019).

The YSL gene family was first characterized in maize and found to be involved in acquisition of $\mathrm{Fe}^{3+}$-PS complexes from the soil (Curie et al., 2001). In rice, OsYSL15 performs $\mathrm{Fe}^{3+}$ PS uptake into root outer cells, and its expression is increased under Fe deficiency in roots (Inoue et al., 2009; Lee et al., 2009). OsYSL15 is also expressed in developing seeds (Inoue et al., 2009; Lee et al., 2009), and knockout osysl15 plants show decreased Fe seed concentration although overexpression of OsYSL15 results in the opposite phenotype (Lee et al., 2009). Although these data suggest that OsYSL15 may be involved in the control of Fe concentration in seeds, it is not possible to separate the role of OsYSL15 in Fe primary uptake and Fe loading based on the current evidence.

Nicotianamine (NA) is a ubiquitous metal-chelating nonproteinogenic amino acid in land plants. NA is a synthesized from three molecules of S-adenosyl-methionine by NA synthase (NAS) and can either be a substrate for phytosiderophore synthesis or chelate metals and function in long distance transport. In A. thaliana, four NAS genes were shown to have roles in $\mathrm{Fe}$ distribution, presumably through Fe-NA binding and translocation in the phloem (Klatte et al., 2009; see below about Fe-NA transporters). NAS genes from barley and rice were also overexpressed in soybean, tobacco, sweet potato, and rice (or expressed under control of endosperm-specific promotor) to increase $\mathrm{Fe}$ translocation to seeds with promising advances for biofortification (reviewed by Nozoye, 2018). Despite the usefulness of NAS genes in transgenic approaches, little is known about their specific physiological function in cereals.

Rice has three NAS genes, OsNAS1, OsNAS2, and OsNAS3 (Inoue et al., 2003). From these, OsNAS1 and OsNAS2 are strongly upregulated under Fe deficiency, whereas OsNAS3 is induced upon Fe excess (Nozoye, 2018). OsNAS3 is shown to be important for $\mathrm{Fe}$ translocation within the plant because knockout osnas 3 plants have decreased Fe levels in flag leaves and seeds, whereas plants with increased expression of OsNAS3 by activation tagging (OsNAS3-D1) show the opposite phenotype (Lee et al., 2009). The same knockout osnas 3 plants are shown to be more sensitive to Fe excess, and OsNAS3-D1 plants are more tolerant to Fe deficiency (Lee et al., 2009; Nozoye et al., 2019), suggesting that endogenous NA is important for Fe translocation and detoxification under Fe toxicity conditions.

OsYSL2 is an $\mathrm{Fe}^{2+}$-NA plasma membrane transporter that loads Fe into phloem cells (Koike et al., 2004) and is required for $\mathrm{Fe}$ translocation to seeds, especially to the endosperm (Ishimaru et al., 2010). Similarly, the plasma membrane-localized transporter OsYSL13 is involved in Fe distribution from old leaves to younger leaves under Fe deficiency conditions. Loss-offunction plants for OsYSL13 showed decreased Fe concentration in seeds, which indicates that long-distance transport of $\mathrm{Fe}$ is mediated by YSL family members and is important for controlling Fe concentration in seeds (Zhang et al., 2018b).

OsYSL9 is shown to transport both $\mathrm{Fe}^{2+}-\mathrm{NA}$ and $\mathrm{Fe}^{3+}-\mathrm{DMA}$ and linked to the Fe deficiency response (Senoura et al., 2017). OsYSL9 is strongly expressed in reproductive tissues, especially in the scutellum and inner regions of the endosperm during seed development. OsYSL9-knockdown plants show decreased Fe in embryos but increased Fe in the endosperm. Therefore, OsYSL9 is involved in embryo Fe loading from the endosperm through the scutellum and might be a good target for biofortification (Senoura et al., 2017).

One of the most exciting findings in the quest to identify transporters that control Fe loading in cereal seeds is the functional characterization of vacuolar iron transporter (VIT) family genes in rice, OsVIT1 and OsVIT2 (Zhang et al., 2012). Both genes are homologous to AtVIT1, which controls $\mathrm{Fe}$ localization in A. thaliana (Kim et al., 2006). OsVIT1 and OsVIT2 were suggested to store Fe in vacuoles of flag leaf cells, decreasing Fe availability for translocation to developing seeds via phloem. This is consistent with the finding that osvit1 and osvit 2 knockout mutant plants have increased $\mathrm{Fe}$ in seeds due to less Fe storage in leaf cell vacuoles and increased translocation (Zhang et al., 2012). This finding is confirmed in an independent work (Bashir et al., 2013). Moreover, both studies found that seeds of osvit1 and osvit 2 changed Fe distribution within the embryo (Zhang et al., 2012; Bashir et al., 2013). Interestingly, TaVIT2 (but not TaVIT1) overexpression using an endosperm-specific promoter increased Fe accumulation in the white flour fraction in wheat and barley grains, supporting the usefulness of these genes in biofortification by increasing endosperm sink strength (Connorton et al., 2017).

Regulation of $\mathrm{Fe}$ deficiency response is linked to the concentration of $\mathrm{Fe}$ in seeds. The HRZ [Haemerythrin motifcontaining Really Interesting New Gene (RING)- and Zinc-finger protein 1] genes from rice are homologs of BRUTUS/BRUTUSlike proteins from $A$. thaliana, which are shown to be negative regulators of the $\mathrm{Fe}$ deficiency response at the posttranscriptional level (Hindt et al., 2017; Rodriguez-Celma et al., 2019). OsHRZ1 and OsHRZ2 knockdown plants showed tolerance to low $\mathrm{Fe}$ and grew better in calcareous soil, in which $\mathrm{Fe}$ is less available. Increased protein levels of Fe uptake transporters are a likely explanation for this phenotype because degradation of upstream transcription factors, presumably targets of OsHRZ1 and OsHRZ2, is decreased (Kobayashi et al., 2013). Interestingly, the authors found that OsHRZ1 and OsHRZ2 knockdown plants show increased $\mathrm{Fe}$ concentration in brown rice, indicating that higher $\mathrm{Fe}$ uptake in roots can increase $\mathrm{Fe}$ loading in seeds indirectly.

The mitochondrial iron regulated (MIR) gene was found to indirectly control Fe concentration in rice seeds (Ishimaru et al., 2009; de Oliveira et al., 2020). Plants that have no functional $M I R$ are unable to properly regulate Fe levels as they accumulate more Fe in roots, shoots, and seeds while having constitutively high expression of Fe uptake genes (Ishimaru et al., 2009). This is consistent with data showing that OsIRT1 (the rice $\mathrm{Fe}^{2+}$ transporter involved in Fe uptake) overexpression leads to increased Fe in roots, shoots, and seeds (Lee and An, 2009). Therefore, increased Fe uptake by roots seems to indirectly affect Fe loading in seeds.

Another important step for Fe delivery to developing seeds is Fe redistribution from the node. The intricate vasculature of the node allows for nutrients, such as Fe, to be redirected from the xylem transpiration stream to panicles, which requires at least three intervascular transfer steps, and depends on 
transporters for many elements (Yamaji and Ma, 2014, 2017). OsFRDL1 is a citrate transporter necessary for Fe transport to reproductive tissues. OsFRDL1 is the functional equivalent of A. thaliana AtFRD3, i.e., citrate efflux to the xylem for $\mathrm{Fe}^{3+}$. citrate complex formation, a necessary step for Fe translocation from roots to shoots through the transpiration stream (Rogers and Guerinot, 2002; Green and Rogers, 2004; Yokosho et al., 2009; Roschzttardtz et al., 2011). OsFRDL1 is also expressed in shoots, mainly in vascular tissues, including leaves, nodes, peduncle, rachis, filament of the anthers, and husk. Knockout plants for OsFRDL1 show significantly decreased pollen viability and fertility compared with wild type. Interestingly, Fe deposition in the parenchyma cell bridges of the nodes, where $\mathrm{Fe}$ (and $\mathrm{Zn}$ ) accumulates in wild type, is higher in mutant plants, whereas Fe concentration in flag leaves is lower. Taken together, the data suggest that OsFRDL1 is important for Fe solubilization and transport to panicles from nodes (Yokosho et al., 2016).

Recently, OsVMT/OsZIFL12 was linked to $\mathrm{Fe}$ (and $\mathrm{Zn}$ ) translocation to grains (Che et al., 2019). OsVMT is localized in the vacuole and has DMA transport activity. At the vegetative stage, OsVMT is highly expressed in the exodermis and endodermis of roots, and at the reproductive stage, at the parenchyma cell bridges of the node I (Che et al., 2019). The authors suggest that OsVMT is involved in sequestering DMA into root vacuoles, which is necessary for $\mathrm{Fe}^{3+}$-DMA complex formation and subsequent export from vacuoles and loading in xylem, where $\mathrm{Fe}^{3+}$-DMA is translocated to shoots (Che et al., 2019). Accordingly, osvmt mutants show increased $\mathrm{Fe}$ and $\mathrm{Zn}$ concentration in polished seeds. The authors suggest that, because OsVMT is highly expressed in the parenchyma cell bridges, an anatomical region that accumulates $\mathrm{Fe}$ and $\mathrm{Zn}$ (Moore et al., 2014; Yamaji and Ma, 2019), the lack of functional OsVMT leads to higher DMA in the cytosol, which solubilizes more $\mathrm{Fe}$ (and $\mathrm{Zn}$ ), increasing translocation and loading into seeds. The accumulation of DMA in polished seeds of mutant plants compared with wild-type (Che et al., 2019) supports this hypothesis. Therefore, rice uses both DMA and citrate to chelate Fe for translocation from nodes to developing seeds, suggesting that, as with other nutrients, control of nutrient transport in the node is key for Fe loading in seeds.

One important regulator of $\mathrm{Fe}, \mathrm{Zn}$, and protein levels in wheat (T. turgidum ssp. durum) seeds, a NAC transcription factor named $N A M-B 1$, was described years ago. NAM-B1 is non-functional in modern pasta wheat varieties, whereas in the ancestral wild emmer wheat (T. turgidum ssp. dicoccoides), it is fully functional. Introgression lines and RNAi experiments show that the reduced/loss of function of NAM-B1 leads to delayed senescence and decreased Fe levels in grains, indicating that senescence timing is important for $\mathrm{Fe}$ translocation to seeds (Uauy et al., 2006). However, no gene with similar function was found in rice despite several efforts (Sperotto et al., 2009; Distelfeld et al., 2012; Jeong et al., 2013). Therefore, wild relatives of wheat are an interesting source of genetic variability for improving $\mathrm{Fe}$ concentration in cultivated wheat varieties, an approach that can be used with wild rice species (Ricachenevsky and Sperotto, 2016; Bierschenk et al., 2020; Wairich et al., 2020).
Although gene functional characterization has been prolific in the last few years, we are still lacking a comprehensive model of how rice plants transport Fe from root uptake to delivery to seeds. Major questions are still open, such as how many transporters are relevant for $\mathrm{Fe}$ (either $\mathrm{Fe}^{3+}$ or $\mathrm{Fe}^{2+}$ ) uptake in roots, how they work in concert to achieve optimal Fe nutrition, and how $\mathrm{Fe}$ is delivered and loaded in the developing seed. Moreover, there is no information on genes directly linked to natural variation in Fe seed concentration or to Fe homeostasis in general in rice. Increasing our basic gene function in Fe homeostasis, combined with the number of QTLs already identified, should help fill that gap in the future.

\section{QTLS ASSOCIATED WITH FE CONCENTRATION IN RICE GRAINS}

Increasing the bioavailable $\mathrm{Fe}$ concentration in the rice endosperm is the major goal of the rice Fe-biofortification program (Mayer et al., 2008; Shahzad et al., 2014). However, conventional breeding efforts to develop high-Fe rice have not been successful except for the release of a high-Fe rice variety NSIC Rc172 (MS13). This variety was developed by crossing IR72, a high-yielding rice variety, with a tall traditional rice land race, Zawa Bonday. It has higher levels of $\mathrm{Fe}$ in both brown and white rice and possesses excellent agronomic, grain, and cooking quality traits (Gregorio et al., 2000; Swamy et al., 2016). Even the bioefficacy feeding trials using this rice variety showed increased $\mathrm{Fe}$ status in the human body and made positive health impacts (Haas et al., 2005). But there were not many concerted efforts to scale up and disseminate this product, and it failed to upgrade the variety with improved tolerance to prevailing biotic and abiotic stresses.

The narrow genetic variation, complex genetic architecture, huge genotype and environmental interactions are the major constraints for developing a high-Fe rice by traditional breeding (Kawakami and Bhullar, 2018; Connorton and Balk, 2019; Ludwig and Slamet-Loedin, 2019). Therefore, understanding the molecular basis, particularly identification of causative genes linked to variation in Fe concentration in seeds of several rice genotypes is instrumental for generating biofortified cultivars. However, to date, no such gene was isolated despite the number of QTLs mapped. Here we summarize the known QTLs that could be useful for rice Fe biofortification (Table 1).

We reviewed 20 published papers that focused on QTL identification for $\mathrm{Fe}$ concentration in rice and closely related species. Overall, 93 QTLs and 50 metal homeostasis-related candidate genes have been reported in rice with the highest number of QTLs reported on chromosomes 1, 3, and 7 (Figure 1 and Table 1). Seventeen Fe QTLs detected on chromosomes $1-4,6-8,10$, and 11 were stable across different seasons, locations, environments, and populations. Some of the most prominent stable $\mathrm{Fe}$ QTLs are $q F e_{1}, q F e_{1.1}, q F e_{1.2}, q F e_{2-1}$, $q \mathrm{Fe}_{3.1}, q \mathrm{Fe}_{3-1}, q \mathrm{Fe}_{6.1}, q \mathrm{Fe}_{6.2}, q F e_{7}, q \mathrm{Fe}_{8.2}, q \mathrm{Fe}_{10 \cdot 1}$, and $q F e_{11}$. It is interesting to note that several positive QTL alleles for increased Fe concentration were contributed by wild rice species, such as $O$. nivara and $O$. rufipogon, deep water rice 
TABLE 1 | List of QTLs and candidate genes reported for iron concentration in rice.

\begin{tabular}{|c|c|c|c|c|c|c|c|c|}
\hline Population & Parents & Lines & Env & Chr & No. of QTLs & QTLs & $R^{2}(\%)$ & References \\
\hline Multiple crosses & - & - & - & $7,8,9$ & 3 & & $19-30$ & $\begin{array}{l}\text { Gregorio et al., } \\
2000\end{array}$ \\
\hline $\mathrm{DH}$ & IR64/Azucena & 129 & 1 & $2,8,12$ & 3 & & $14-18$ & $\begin{array}{l}\text { Stangoulis et al., } \\
2007\end{array}$ \\
\hline RILs & Zhenshan 97/Minghui 63 & 241 & 1 & 1,9 & 2 & $q F e-1, q F e-9$ & $11-26$ & Lu et al., 2008 \\
\hline ILs & Teqing/O. rufipogon & 85 & 1 & 2,9 & 2 & qFe2-1, qFe9-1 & $5-7$ & $\begin{array}{l}\text { Garcia-Oliveira } \\
\text { et al., } 2009\end{array}$ \\
\hline RILs & Bala/Azucena & 105 & 1 & $1,3,4,7$ & 4 & qFe1, qFe3, qFe4, qFe7 & $10-21$ & $\begin{array}{l}\text { Norton et al., } \\
2010\end{array}$ \\
\hline RILs & Madhukar/Swarna & 168 & 1 & $1,5,7,12$ & 7 & $\begin{array}{l}\text { qFe1.1, qFe1.2, qFe5.1, qFe7.1, } \\
\text { qFe7.2, qFe12.1, qFe12.2 }\end{array}$ & $69-71$ & $\begin{array}{l}\text { Anuradha et al., } \\
2012\end{array}$ \\
\hline $\mathrm{DH}$ & Chunjiang 06/TN1 & 120 & 2 & $1,6,8$ & 3 & & $11-22$ & Du et al., 2013 \\
\hline $\mathrm{F}_{2}$ & Swarna/Madhukar & 178 & 1 & 3,4 & 3 & & $1-13$ & $\begin{array}{l}\text { Nagesh et al., } \\
2013\end{array}$ \\
\hline RILs, ILs & Lemont/TeQing & $280 / 123$ & 2 & $\begin{array}{c}1,2,3,4,5,6 \\
7,8,10\end{array}$ & 13 & & $3-5$ & $\begin{array}{l}\text { Zhang et al., } \\
2014\end{array}$ \\
\hline BILs & $\begin{array}{l}\text { IR75862/Ce258; IR75862/ } \\
\text { Zhongguangxiang1 }\end{array}$ & 401 & 2 & $1,2,6,7,11$ & 5 & qFe1, $q F e 2, q F e 6, q F e 7, q F e 11$ & $6-18$ & Xu et al., 2015 \\
\hline BILs & Xieqingzao $\times$ O. rufipogon & 202 & 2 & $3,6,9$ & 3 & qFe3, qFe6, qFe9 & $6-28$ & Hu et al., 2016 \\
\hline $\mathrm{BC}_{2} \mathrm{~F}_{2}$ & $\begin{array}{l}\text { Swarna } \times \text { O. nivara } \\
(\text { IRGC81832, IRGC81848) }\end{array}$ & $245 / 227$ & 1 & $\begin{array}{c}1,2,3,4,6,8 \\
11,12\end{array}$ & 15 & $\begin{array}{l}q F e_{1.1}, q F e_{1.2}, q F e_{1.3}, q F e_{2.1}, q F e_{2.2} \\
q F e_{3.1}, q F e_{3.2}, q F e_{4.1}, q F e_{6.1}, q F e_{8.1} \\
q F e_{8.2}, q F e_{11.1}, q F e_{11.2}, q F e_{11.3} \\
q F e_{12.1}\end{array}$ & $4-25$ & $\begin{array}{l}\text { Swamy et al., } \\
2018 b\end{array}$ \\
\hline Multiparent & MAGIC Plus & 144 & 4 & $3,7,9,10,11$ & 7 & $\begin{array}{l}q \mathrm{Fe}_{3.1}, q \mathrm{Fe}_{3.2}, q \mathrm{Fe}_{7.1}, q \mathrm{Fe}_{9.1}, q \mathrm{Fe}_{9.2} \\
\mathbf{q F e _ { 1 0 . 1 }}, q F e_{11.1}\end{array}$ & $9-14$ & $\begin{array}{l}\text { Descalsota et al., } \\
2018\end{array}$ \\
\hline $\mathrm{DH}$ & $\begin{array}{l}\text { PSBRc82 × Joryeongbyeo; } \\
\text { PSBRc82 × IR69428 }\end{array}$ & $130 ; 97$ & 2 & 4 & 1 & $q \mathrm{Fe}_{4.1}$ & 9 & $\begin{array}{l}\text { Swamy et al., } \\
2018 a\end{array}$ \\
\hline Panel & colored rice accessions & 152 & 2 & 6,12 & 2 & $q \mathrm{Fe}_{6.1}, q \mathrm{Fe}_{12.1}$ & $10.3-10.6$ & $\begin{array}{l}\text { Descalsota- } \\
\text { Empleo et al., } \\
2019 a, b\end{array}$ \\
\hline $\mathrm{BC}_{2} \mathrm{~F}_{5}$ & RP Bio-226 × Sampada & 111 & 2 & 1,6 & 4 & $q F e_{1.1}, q F e_{1.2}, q F e_{6.1}, q F e_{6.2}$ & $1-17$ & Dixit et al., 2019 \\
\hline RILs & PAU201 × Palman 579 & 177,106 & 1 & $5,7,9$ & 5 & $q F E_{5 \cdot 1}, q F E_{5 \cdot 2}, q F E_{5 \cdot 3}, q F E_{7 \cdot 1}, q F E_{9 \cdot 1}$ & 35-95 & $\begin{array}{l}\text { Kumar et al., } \\
2019\end{array}$ \\
\hline $\mathrm{DH}$ & IR05F102 × IR69428 & 148 & 3 & 9,12 & 2 & $q \mathrm{Fe}_{9.1}, q \mathrm{Fe}_{12.1}$ & $12-13$ & $\begin{array}{l}\text { Calayugan et al., } \\
2020\end{array}$ \\
\hline $\mathrm{DH}$ & 93-11 × Milyang 352 & 123 & 2 & 3 & 7 & $q \mathrm{Fe}_{3-1}, q \mathrm{Fe}_{3-2}$ & $11-17$ & Lee et al., 2020 \\
\hline $\mathrm{DH}$ & Goami 2' × "Hwaseonchal" & 110 & 1 & $1,4,6,7,11$ & & $\begin{array}{l}q \mathrm{Fe}_{1.1}, q \mathrm{Fe}_{1.2}, q \mathrm{Fe}_{1.3}, q \mathrm{Fe} 4,1 \mathrm{qFe} 6 \\
q \mathrm{Fe} 7, \mathrm{qFe} 11\end{array}$ & $12-41$ & $\begin{array}{l}\text { Jeong et al., } \\
2020\end{array}$ \\
\hline
\end{tabular}

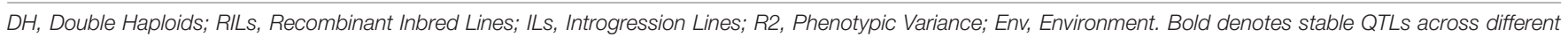
seasons, locations, environments, and populations.

Madhukar and Jalamagna, and land races (Anuradha et al., 2012; Swamy et al., 2018b). The stability of the Fe QTLs in multiple populations and environments and their association with candidate genes involved in Fe homeostasis makes them useful for MAB or genomic selection (GS) and for further molecular characterization to understand the molecular mechanisms.

A total of 25 QTLs harbor known metal or Fe homeostasisrelated candidate genes nearby or within the QTL. The highest number of reported Fe QTL with clear Fe homeostasis related candidate genes were on chromosomes 1, 3, 4, and 7 (Table 2). These genes were found to be involved in $\mathrm{Fe}$ acquisition in roots, biosynthesis of root exudates, uptake, translocation, and loading of $\mathrm{Fe}$ into different tissues/organs and to rice grains (Table 2). Some of the Fe homeostasis genes, such as OsNAS1, OsNAS2, OsFer, OsVIT1, OsVIT2, OsZIP, OsIRO2, and OsIRT1, have already successfully been cloned, and transgenics have been developed, which had up to a sixfold increase in $\mathrm{Fe}$ concentration and fourfold increase in $\mathrm{Zn}$ concentration compared to their respective base lines (Masuda et al., 2013; Kawakami and Bhullar, 2018). It is also interesting note that Fe and $\mathrm{Zn}$ loading pathways seem to be shared because increasing Fe usually results in increased $\mathrm{Zn}$ as well. Evidence for such shared pathways for $\mathrm{Fe}$ and $\mathrm{Zn}$ loading are emerging in other grasses, such as wheat (Astolfi et al., 2018). Still, most of the Fe accumulates in the brown rice, and a significant portion of the $\mathrm{Zn}$ accumulates in the endosperm (Johnson et al., 2011). Therefore, it might be feasible to generate biofortified rice varieties for both micronutrients simultaneously.

The narrow genetic variation for Fe concentration in polished rice in the readily useable primary gene pool of rice (i.e., species with AA genome, closely related to Oryza sativa) is a major constraint. There is a need to revisit the gene bank and 


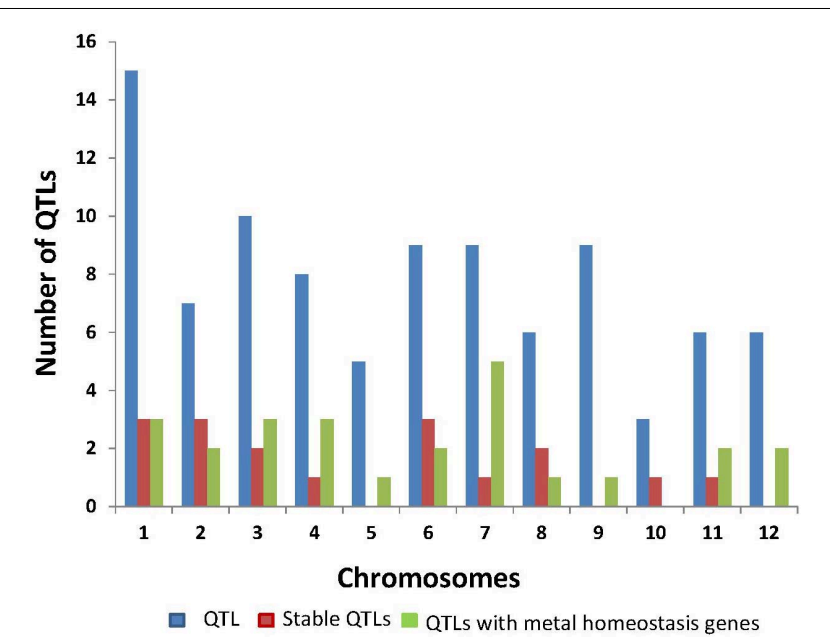

FIGURE 1 | Summary of Fe QTLs and genes reported from different studies in rice.

screen gene bank accessions, especially wild rice and land races using more accurate and advanced Fe phenotyping protocols. This will help to identify potential high-Fe parental lines for discovery of major QTLs and use in breeding programs. Even though several major effect grain Fe QTLs explained very high phenotypic variance $(>10 \%)$ and also gene-specific markers have been reported in rice (Table 1), there is no successful example of an Fe-biofortified rice genotype generated by QTL based MAB.

There is a huge potential to use these markers in MAB and GS to improve the grain $\mathrm{Fe}$ concentration in rice. Because there are multiple QTLs/genes responsible for grain Fe concentration located on different chromosomes, MAB through QTL pyramiding, rapid cycle recurrent selection (RCRS), and genomics assisted selection breeding approaches are worth trying to develop high-Fe rice. Genome wide association studies (GWAS) and GS approaches have not been explored much for improving grain micronutrients, but they hold great promise for improving the grain $\mathrm{Fe}$ concentration of several popular rice varieties and are highly useful in mainstreaming of rice Fe breeding. Moreover, genetic engineering and gene editing technologies have successfully demonstrated their potential to elevate levels of $\mathrm{Fe}$ in rice and improve bioavailability (Trijatmiko et al., 2016). Breeding programs have been initiated to transfer high-Fe traits using transgenic approaches into popular rice varieties through MAB (Paul et al., 2014; MorenoMayano et al., 2016).

Last, it is important to note that development of multiple nutrient-rich rice varieties with reduced levels of toxic elements, such as cadmium and arsenic, is also essential for the success of breeding for healthier rice (Van Der Straeten et al., 2020). Several advanced breeding materials, such as MAGIC populations, wild rice-derived introgression lines, and multicross-derived advanced breeding lines, are being developed, which are valuable genetic resources for genetic dissection of multiple nutrient elements (Swamy et al., 2016). Recently IRRI is leading the mainstream breeding for $\mathrm{Zn}$ biofortification, which aims to incorporate grain $\mathrm{Zn}$ as an important component of all future rice varieties. Similar efforts should be made for Fe mainstreaming in rice.

\section{POSSIBLE CANDIDATE GENES WITH KNOWN FUNCTION WITHIN QTL REGIONS}

Among the most promising candidate genes identified, we highlight transporters from the YSL gene family (Table 2). Besides the role of OsYSL15 in $\mathrm{Fe}^{3+}$-PS transport (Inoue et al., 2009; Lee et al., 2009), other members were shown to perform Fe long-distance transport (Curie et al., 2009). OsYSL9 has a role in Fe transport to rice grains, specifically in Fe transfer from the endosperm to the embryo because plants silenced for OsYSL9 show decreased Fe concentrations in embryos but increased in other seed regions (Senoura et al., 2017). OsYSL16 has been linked to transport of Cu-NA complexes (Zheng et al., 2012; Zhang et al., 2018a) and also play a role in Fe long-distance transport (Kakei et al., 2012). Recently, OsYSL18 was shown to remobilize Fe from old to young leaves and to developing seeds (Zhang et al., 2018a). Therefore, the fact that some OsYSL genes coincide with QTLs is quite promising.

In agreement with a role of long-distance transport in determining final Fe concentration in seeds, there are QTLs colocalizing with the two loci that harbor the three NA synthase (NAS) genes (Table 2). Rice has three NAS genes (two of them are in tandem) for which the precise roles are not fully understood. Biofortification efforts using transgenics commonly increase NAS gene expression, presumably to increase NA-mediated Fe transport to developing seeds, a strategy that has been fruitful alone and in combination with other transgenes (Inoue et al., 2003; Johnson et al., 2011; Lee et al., 2011; Trijatmiko et al., 2016). It would not be surprising to find that NAS genes are linked to variation in $\mathrm{Fe}$ concentration in rice genotypes. One NA amino transferase (NAAT) gene (Inoue et al., 2008), which is involved in PS synthesis, was also found within a QTL (Table 2), highlighting how changes in metal chelators might be important for controlling Fe concentration in seeds.

The ZIP gene family also has promising candidate genes (Table 2). Among them, OsZIP1 was suggested to detoxify $\mathrm{Zn}$, $\mathrm{Cd}$, and $\mathrm{Cu}$ from rice roots but not Fe (Liu et al., 2019b). OsZIP4 was recently shown to function in $\mathrm{Zn}$ distribution to tiller buds and panicles (Mu et al., 2020). OsZIP8 (Lee et al., 2010) and OsZIP7 (Ricachenevsky et al., 2018; Tan et al., 2019; Gindri et al., 2020 ) both are $\mathrm{Zn}$ transporters with roles in $\mathrm{Zn}$ root-to-shoot translocation. However, none of these transporters is shown to be relevant for Fe homeostasis. OsZIP6, which also coincides with a QTL (Table 2), is shown to transport Fe (Kavitha et al., 2015) although its physiological role in planta is unknown. Still, given that Fe and $\mathrm{Zn}$ homeostasis do crosstalk and the translocation mechanisms to seeds seem to be at least partially shared, it is interesting to pursue whether these genes might explain variation in rice genotypes for $\mathrm{Fe}$ concentration in seeds.

Other interesting candidate genes are from the NRAMP gene family (Table 2). OsNRAMP1 is part of the Fe deficiency regulon, 
TABLE 2 | Biological functions of QTL linked candidate genes for Fe concentration.

\begin{tabular}{|c|c|c|c|}
\hline QTL & Gene & Function & References \\
\hline$q F e_{6.1}$ & AtbZIP19, AtbZIP19 & $\begin{array}{l}\text { Zinc accumulation in roots. Mediates } \\
\text { the expression of the ZIP }\end{array}$ & Inaba et al., 2015 \\
\hline$q F e_{12 \cdot 1}$ & APRT (Os12g0589100) & $\begin{array}{l}\text { Phosphate ion transmembrane } \\
\text { transporter activity }\end{array}$ & Zhang et al., 2013 \\
\hline$q \mathrm{Fe}_{4.1}$ & $\begin{array}{l}\text { OsFRO1 (OsO4g0578600), } \\
\text { OsFRO2(LOC_Os04g48930) }\end{array}$ & Fe absorption and homeostasis & Shou et al., 2019 \\
\hline$q F e_{1.2}$ & OsZIP1 (Os01g74110) & Zinc ion transmembrane transport & Liu et al., 2019b \\
\hline \multirow[t]{2}{*}{$q \mathrm{Fe}_{7}$} & $\begin{array}{l}\text { Os07g0510100, Os07g0517900, Os07g0518500, } \\
\text { Os07g0519100, Os07g0519300, Os07g0519600, } \\
\text { Os07g0521000, Os07g0529600, Os07g0556200 }\end{array}$ & Metal ion binding, Iron ion binding & https://www.uniprot.org/uniprot/Q6Z4B5 \\
\hline & OsHMA7 (Os07g0623200) & Copper-transporting ATPase & http://atgenie.org/gene?id=AT5G44790 \\
\hline$q F e_{1.2}, q F e_{6.1}$ & OsIAA5(LOC_Os01g48444.1) & Auxin mediated signaling pathway & Liu et al., 2019a \\
\hline$q F e_{1.2}, q F e_{6.1}$ & OsIAA6 (LOC_Os01g53880.1) & Drought stress responses & Jung et al., 2015 \\
\hline$q \mathrm{Fe}_{6.1}$ & OsLCT1(LOC_Os06g38120.1) & Involved in zinc and cadmium transport & Tian et al., 2019 \\
\hline$q_{F e} .1$ & OsLysM-RLK10(LOC_Os09g33630.3) OsRLCK276 & $\begin{array}{l}\text { ATP binding and protein } \\
\text { self-association }\end{array}$ & https://www.uniprot.org \\
\hline$q \mathrm{Fe}_{5.1}, q \mathrm{Fe}_{3.1}$ & OsMTP1 (Os05g0128400), OsMTP6 (Os03g0346800) & Detoxification of zinc ion & https://www.uniprot.org/uniprot/A2XZZ6 \\
\hline$q \mathrm{Fe}_{2.1}$ & OsNAAT1 (Os02g0306401) & Biosynthesis of mugineic acid & Inoue et al., 2008 \\
\hline$q F e_{11 \cdot 1}$ & OsNAC5 (Os11g0184900) & $\begin{array}{l}\text { Transcription factors possibly } \\
\text { controlling expression of metal-related } \\
\text { genes }\end{array}$ & Sperotto et al., 2009 \\
\hline$q \mathrm{Fe}_{3.1}, q \mathrm{Fe}_{7.1}$ & $\begin{array}{l}\text { OsNAS1 (Os03g0307300), OsNAS2 (Os03g0307200), } \\
\text { OsNAS3 (Os07g0689600) }\end{array}$ & $\begin{array}{l}\text { Synthesizes nicotianamine, metal } \\
\text { uptake, transport and loading }\end{array}$ & $\begin{array}{l}\text { Inoue et al., 2003; Johnson et al., 2011; } \\
\text { Lee et al., 2011; Trijatmiko et al., } 2016\end{array}$ \\
\hline$q F e_{1.1}, q F e_{7.2}$ & $\begin{array}{l}\text { OsNRAMP1 (Os07g0258400), OsNRAMP6 } \\
\text { (Os01g0503400) }\end{array}$ & $\begin{array}{l}\text { Metal transporter controlling iron } \\
\text { homeostasis }\end{array}$ & Curie et al., 2000; Peris-Peris et al., 2017 \\
\hline $\mathrm{qFe}_{4.1}$ & OsOCP (LOC_Os04g55650.2) & Metal uptake, transport, and loading & $\begin{array}{l}\text { https://shigen.nig.ac.jp/rice/oryzabase/ } \\
\text { gene/detail/589. }\end{array}$ \\
\hline$q F e_{12 \cdot 1}$ & OsSWEET1, OSSWEET13 & $\begin{array}{l}\text { Mediates both low-affinity uptake and } \\
\text { efflux of sugar across the plasma } \\
\text { membrane, haem binding }\end{array}$ & https://www.uniprot.org/uniprot/Q60EC2 \\
\hline $\begin{array}{l}q F e_{1.2}, F_{4.1} \\
q F e_{5.1}, F_{8.2}\end{array}$ & $\begin{array}{l}\text { OsYSL1 (LOC_Os01g13710.1), OsYSL4 } \\
\text { (LOC_Os05g16290.1), OsYSL8(LOC_Os02g02460.1), } \\
\text { OsYSL9 (LOC_Os04g45860.1), OsYSL16 } \\
\text { (LOC_Os04g45900.1),OsYSL17 (LOC_Os08g17830.1) }\end{array}$ & $\begin{array}{l}\text { Transport of nicotianamine-chelated } \\
\text { metals }\end{array}$ & $\begin{array}{l}\text { Ishimaru et al., 2010; Sasaki et al., 2011; } \\
\text { Inoue et al., 2009; Kakei et al., } 2012\end{array}$ \\
\hline $\begin{array}{l}\mathrm{qFe}_{1.2} \mathrm{Fe}_{5.1} \\
q \mathrm{Fe}_{7.2}, \mathrm{qFe}_{8.2}\end{array}$ & $\begin{array}{l}\text { OsZIP1 (Os01g0972200), OsZIP4 (Os08g0207500), } \\
\text { OsZIP6 (Os05g0164800), OsZIP7 (Os05g0198400), } \\
\text { OsZIP8 (Os07g0232800) }\end{array}$ & $\begin{array}{l}\text { Zinc transporter that may mediate zinc } \\
\text { uptake from the rhizosphere }\end{array}$ & $\begin{array}{l}\text { Ramesh et al., 2003; Ishimaru et al., } \\
\text { 2007; Ricachenevsky et al., 2018; Liu } \\
\text { et al., 2019b }\end{array}$ \\
\hline
\end{tabular}

being induced upon low $\mathrm{Fe}$ concentration in roots (Wairich et al., 2019). OsNRAMP1 is very similar to OsNRAMP5, a wellknown transporter for controlling Cd concentrations in seeds. OsNRAMP1 was recently shown to transport $\mathrm{Cd}$ and $\mathrm{Mn}$ but not $\mathrm{Fe}$ or As as previously suggested (Chang et al., 2020). OsNRAMP6, on the other hand, is an Fe and Mn transporter, which undergoes alternative splicing. Both splicing isoforms can transport Fe and might be negatively linked to plant immunity (Peris-Peris et al., 2017).

Finally, we find that OsHMA7 is within a QTL. The OsHMA7 allelic variation was analyzed in recombinant inbred lines generated from crosses between Madhukar $\times$ Swarna, which show high and low Fe concentration in seeds, respectively (Kappara et al., 2018). Results show that lines silenced for OsHMA7 or overexpressing either alleles result in complex phenotypes with changes in plant size and domestication traits. However, the over-expression of the allele from the high-Fe genotype results in increased $\mathrm{Fe}$ concentration in seeds, whereas the overexpression of the allele from the low-Fe genotype did not (Kappara et al., 2018). Therefore, OsHMA7, despite not having its molecular function characterized yet, is a good candidate gene for natural variation in $\mathrm{Fe}$ levels in rice grains.

\section{CONCLUSION}

The QTLs and candidate genes reviewed here are a useful resource for future Fe biofortification efforts. From a practical standpoint, further QTL pyramiding using robust regions associated with high Fe concentrations might be feasible because many studies now support some of the same regions as linked to high Fe concentration in seeds. Still, efforts to identify causative genes and specific mutations linked to Fe accumulation in rice seeds would improve our understanding of the genetic basis for such variation, indicate which mechanisms are amenable 
to manipulation in rice plants for increasing Fe in seeds, and finally allow precise introgression of such genetic variants into elite genotypes using markers linked to causative mutations of the desired phenotypes. The information provided here will help future studies focused on such aims.

\section{AUTHOR CONTRIBUTIONS}

All authors contributed equally to writing the manuscript and reviewing and preparing the submission.

\section{REFERENCES}

Abbaspour, N., Hurrell, R., and Kelishadi, R. (2014). Review on iron and its importance for human health. J. Res. Med. Sci. 19, 164-174.

Anuradha, K., Agarwal, S., Batchu, A. K., Babu, A. P., Swamy, B. P. M., Longva, T., et al. (2012). Evaluating rice germplasm for iron and zinc concentration in brown rice and seed dimensions. J. Phytol. 4, 19-25.

Astolfi, S., Pii, Y., Terzano, R., Mimmo, T., Celletti, S., Allegretta, I., et al. (2018). Does Fe accumulation in durum wheat seeds benefit from improved wholeplant sulfur nutrition? J. Cereal Sci. 83, 74-82. doi: 10.1016/j.jcs.2018.07. 010

Aznar, A., Chen, N. W., Thomine, S., and Dellagi, A. (2015). Immunity to plant pathogens and iron homeostasis. Plant Sci. 240, 90-97. doi: 10.1016/j.plantsci. 2015.08.022

Balk, J., and Schaedler, T. A. (2014). Iron cofactor assembly in plants. Annu. Rev. Plant Biol. 65, 125-153. doi: 10.1146/annurev-arplant-050213-035759

Bashir, K., Takahashi, R., Akhtar, S., Ishimaru, Y., Nakanishi, H., and Nishizawa, N. K. (2013). The knockdown of OsVIT2 and MIT affects iron localization in rice seed. Rice 6:31. doi: 10.1186/1939-8433-6-31

Bierschenk, B., Tagele, M. T., Ali, B., Ashrafuzzaman, M. D., Wu, L. B., Becker, M., et al. (2020). Evaluation of rice wild relatives as a source of traits for adaptation to iron toxicity and enhanced grain quality. PLoS One 15:e0223086. doi: 10.1371/journal.pone.0223086

Briat, J. F., Dubos, C., and Gaymard, F. (2015). Iron nutrition, biomass production, and plant product quality. Trends Plant Sci. 20, 33-39. doi: 10.1016/j.tplants. 2014.07.005

Calayugan, M. I. C., Formantes, A. K., Amparado, A., Descalsota-Empleo, G. I., Nha, C. T., Inabangan-Asilo, M. A., et al. (2020). Genetic analysis of agronomic traits and grain iron and zinc concentrations in a doubled haploid population of rice (Oryza sativa L.). Sci. Rep. 10:2283. doi: 10.1038/s41598-020-59184-z

Camaschella, C. (2017). New insights into iron deficiency and iron deficiency anemia. Blood Rev. 31, 225-233. doi: 10.1016/j.blre.2017.02.004

Cappellini, M. D., Musallam, K. M., and Taher, A. T. (2019). Iron deficiency anaemia revisited. J. Intern. Med. 287, 153-170.

Cesco, S., Tolotti, A., Nadalini, S., Rizzi, S., Valentinuzzi, F., Mimmo, T., et al. (2020). Plasmopara viticola infection affects mineral elements allocation and distribution in Vitis vinifera leaves. Sci. Rep. 10:18759.

Chang, J. D., Huang, S., Yamaji, Y., Zhang, W., Ma, J. F., and Zhao, F. J. (2020). OsNRAMP1 transporter contributes to cadmium and manganese uptake in rice. Plant Cell Environ. 43, 2476-2491. doi: 10.1111/pce.13843

Chaves, M. M., Flexas, J., and Pinheiro, C. (2009). Photosynthesis under drought and salt stress: regulation mechanisms from whole plant to cell. Ann. Bot. 103, 551-560. doi: 10.1093/aob/mcn 125

Che, J., Yokosho, K., Yamaji, N., and Ma, J. F. (2019). A vacuolar phytosiderophore transporter alters Iron and Zinc accumulation in polished rice grains. Plant Physiol. 181, 276-288. doi: 10.1104/pp.19.00598

Connorton, J. M., and Balk, J. (2019). Iron biofortification of staple crops: lessons and challenges in plant genetics. Plant Cell Physiol. 60, 1447-1456. doi: 10.1093/ pcp/pcz079

Connorton, J. M., Jones, E. R., Rodriguez-Ramiro, I., Fairweather-Tait, S., Uauy, C., and Balk, J. (2017). Wheat vacuolar Iron transporter TaVIT2 transports Fe and Mn and is Effective for biofortification. Plant Physiol. 174, 2434-2444. doi: 10.1104/pp.17.00672

\section{FUNDING}

This work was supported by the Instituto Serrapilheira (grant no. Serra-1709-17256), the Conselho Nacional de Desenvolvimento Científico e Tecnológico (CNPq), and the Fundação de Amparo à Pesquisa do Rio Grande do Sul-FAPERGS (Pronex process 16/25.51-0000493-5), Brazil; and by Portuguese national funds of the Fundação para a Ciência e a Tecnologia to the research unit UIDB/00239/2020 (CEF). We acknowledge BMGF for funding mainstreaming rice biofortification project, International Rice Research Institute.

Conte, S. S., and Walker, E. L. (2012). Genetic and biochemical approaches for studying the yellow stripe-like transporter family in plants. Curr. Top. Membr. 69, 295-322. doi: 10.1016/B978-0-12-394390-3.00011-2

Curie, C., Alonso, J. M., Jean, M. L., Ecker, J. R., and Briat, J. F. (2000). Involvement of NRAMP1 from Arabidopsis thaliana in iron transport. Biochem. J. 347, 749-755. doi: 10.1042/bj3470749

Curie, C., Cassin, G., Couch, D., Divol, F., Higuchi, K., Le Jean, M., et al. (2009). Metal movement within the plant: contribution of nicotianamine and yellow stripe 1-like transporters. Ann. Bot. 103, 1-11. doi: 10.1093/aob/mcn207

Curie, C., Panaviene, Z., Loulergue, C., Dellaporta, S. L., Briat, J. F., and Walker, E. L. (2001). Maize yellow stripe1 encodes a membrane protein directly involved in Fe (III) uptake. Nature 409, 346-349. doi: 10.1038/35053080

de Oliveira, B. H. N., Wairich, A., Turchetto-Zolet, A. C., Fett, J. P., and Ricachenevsky, F. K. (2020). The Mitochondrial Iron Regulated (MIR) gene is Oryza genus-specific and evolved before the speciation within the Oryza sativa complex. Planta 251:94. doi: 10.1007/s00425-020-03386-2

Descalsota, G. I. L., Swamy, B. P. M., Zaw, H., Inabangan-Asilo, M. A., Amparado, A., Mauleon, R., et al. (2018). Genome-wide association mapping in a rice MAGIC Plus population detects QTLs and genes useful for biofortification. Front. Plant Sci. 9:1347. doi: 10.3389/fpls.2018.01347

Descalsota-Empleo, G. I., Amparado, A., Inabangan-Asilo, M. A., Tesoro, F., Stangoulis, J., Reinke, R., et al. (2019a). Genetic mapping of QTL for agronomic traits and grain mineral elements in rice. Crop J. 7, 560-572. doi: 10.1016/j.cj. 2019.03.002

Descalsota-Empleo, G. I., Noraziyah, A. A. S., Navea, I. P., Chung, C., Dwiyanti, M. S., Labios, R. J. D., et al. (2019b). Genetic dissection of grain nutritional traits and leaf blight resistance in rice. Genes 10:30. doi: 10.3390/genes1001 0030

Distelfeld, A., Pearce, S. P., Avni, R., Scherer, B., Uauy, C., Piston, F., et al. (2012). Divergent functions of orthologous NAC transcription factors in wheat and rice. Plant Mol. Biol. 78, 515-524. doi: 10.1007/s11103-012-9881-6

Dixit, S., Singh, U. M., Abbai, R., Ram, T., Singh, V. K., Paul, A., et al. (2019). Identification of genomic region(s) responsible for high iron and zinc content in rice. Sci. Rep. 9:8136. doi: 10.1038/s41598-019-43888-y

Du, J., Zeng, D., Wang, B., Qian, Q., Zheng, S., and Ling, H. Q. (2013). Environmental effects on mineral accumulation in rice grains and identification of ecological specific QTLs. Environ. Geochem. Health 3, 161-170. doi: 10.1007/ s10653-012-9473-z

Failla, M. L. (2003). Trace elements and host defense: recent advances and continuing challenges. J. Nutr. 133, S1443-S1447. doi: 10.1093/jn/133.5.1443S

FAO, IFAD, UNICEF, WFP, and WHO (2019). The State of Food Security and Nutrition in the World 2019. Safeguarding Against Economic Slowdowns and Downturns. FAO: Rome.

Garcia-Oliveira, A. L., Tan, L., Fu, Y., and Sun, C. (2009). Genetic identification of quantitative trait loci for contents of mineral nutrients in rice grain. J. Integr. Plant Biol. 51, 84-92. doi: 10.1111/j.1744-7909.2008.00730.x

Gindri, R. G., Navarro, B. B., da Cruz, Dias, P. V., Tarouco, C. P., Nicoloso, F. T., et al. (2020). Physiological responses of rice (Oryza sativa L.) oszip7 loss-offunction plants exposed to varying Zn concentrations. Physiol. Mol. Biol. Plants 26, 1349-1359. doi: 10.1007/s12298-020-00824-z

Gómez-Galera, S., Rojas, E., Sudhakar, D., Zhu, D., Pelacho, A. M., and Capell, T. (2010). Critical evaluation of strategies for mineral fortification of staple food crops. Transgenic Res. 19, 165-180. doi: 10.1007/s11248-009-9311-y 
Green, L. S., and Rogers, E. E. (2004). FRD3 controls iron localization in Arabidopsis. Plant Physiol. 136, 2523-2531. doi: 10.1104/pp.104.045633

Gregorio, G. B., Senadhira, D., Htut, T., and Graham, R. D. (2000). Breeding for trace mineral density in rice. Food Nutr. Bull. 21, 382-386. doi: 10.1177/ 156482650002100407

Grillet, L., and Schmidt, W. (2019). Iron acquisition strategies in land plants: not so different after all. New Phytol. 224, 11-18. doi: 10.1111/nph.16005

Gupta, P. M., Perrine, C. G., Mei, Z., and Scanlon, K. S. (2016). Iron, anemia, and iron deficiency anemia among young children in the United States. Nutrients 8:300. doi: $10.3390 /$ nu 8060330

Haas, J. D., Beard, J. L., Murray-Kolb, L. E., del Mundo, A. M., Felix, A., and Gregorio, G. B. (2005). Iron-biofortified rice improves the iron stores of nonanemic Filipino women. J. Nutr. 135, 2823-2830. doi: 10.1093/jn/135.12. 2823

Hindt, M. N., Akmakjian, G. Z., Pivarski, K. L., Punshon, T., Baxter, I., Salt, D. E., et al. (2017). BRUTUS and its paralogs, BTS LIKE1 and BTS LIKE2, encode important negative regulators of the iron deficiency response in Arabidopsis thaliana. Metallomics 9, 876-890. doi: 10.1039/C7MT00152E

Hu, B. L., Huang, D. R., Xiao, Y. Q., Fan, Y. Y., Chen, D. Z., and Zhuang, J. Y. (2016). Mapping QTLs for mineral element contents in brown and milled rice using an Oryza sativa $\times$ O. rufipogon backcross inbred line population. Cereal Res. Commun. 44, 57-68. doi: 10.1556/0806.43.2015.044

IFPRI (2015). Global Nutrition Report 2015: Actions and Accountability to Advance Nutrition and Sustainable Development. 2015. Washington, DC: International Food Policy Research Institute.

Inaba, S., Kurata, R., Kobayashi, M., Yamagishi, Y., Mori, I., Ogata, Y., et al. (2015). Identification of putative target genes of bZIP19, a transcription factor essential for Arabidopsis adaptation to Zn deficiency in roots. Plant J. 84, 323-334. doi: 10.1111/tpj.12996

Inoue, H., Higuchi, K., Takahashi, M., Nakanishi, H., Mori, S., and Nishizawa, N. K. (2003). Three rice nicotianamine synthase genes, OsNAS1, OsNAS2, and OsNAS3 are expressed in cells involved in long-distance transport of iron and differentially regulated by iron. Plant J. 36, 366-381. doi: 10.1046/j.1365-313x. 2003.01878.x

Inoue, H., Kobayashi, T., Nozoye, T., Takahashi, M., Kakei, Y., Suzuki, K., et al. (2009). Rice OsYSL15 is an iron-regulated iron(III)-deoxymugineic acid transporter expressed in the roots and is essential for iron uptake in early growth of the seedlings. J. Biol. Chem. 284, 3470-3479. doi: 10.1074/jbc.m806042200

Inoue, H., Takahashi, M., Kobayashi, T., Suzuki, M., Nakanishi, H., Mori, S., et al. (2008). Identification and localisation of the rice nicotianamine aminotransferase gene OsNAAT1 expression suggests the site of phytosiderophore synthesis in rice. Plant Mol. Biol. 66, 193-203. doi: 10.1007/s11103-007-9262-8

Ishimaru, Y., Bashir, K., Fujimoto, M., An, G., Itai, R. N., Tsutsumi, N., et al. (2009). Rice-specific mitochondrial iron-regulated gene (MIR) plays an important role in iron homeostasis. Mol. Plant 2, 1059-1066. doi: 10.1093/mp/ssp051

Ishimaru, Y., Masuda, H., Bashir, K., Inoue, H., Tsukamoto, T., Takahashi, M., et al. (2010). Rice metal-nicotianamine transporter, OsYSL2, is required for the long-distance transport of iron and manganese. Plant J. 62, 379-390. doi: 10.1111/j.1365-313X.2010.04158.x

Ishimaru, Y., Masuda, H., Suzuki, M., Bashir, K., Takahashi, M., Nakanishi, H., et al. (2007). Overexpression of the OsZIP4 zinc transporter confers disarrangement of zinc distribution in rice plants. J. Exp. Bot. 58, 2909-2915. doi: 10.1093/jxb/ erm 147

Ishimaru, Y., Suzuki, M., Tsukamoto, T., Suzuki, K., Nakazono, M., Kobayashi, T., et al. (2006). Rice plants take up iron as an Fe3+-phytosiderophore and as $\mathrm{Fe} 2+$. Plant J. 45, 335-346. doi: 10.1111/j.1365-313X.2005.02624.x

Jeong, J. S., Kim, Y. S., Redillas, M. C., Jang, G., Jung, H., Bang, S. W., et al. (2013). OsNAC5 overexpression enlarges root diameter in rice plants leading to enhanced drought tolerance and increased grain yield in the field. Plant Biotechnol. J. 11, 101-114. doi: 10.1111/pbi.12011

Jeong, O.-Y., Lee, J.-H., Jeong, E.-G., Chun, A., Bombay, M., Banzon Ancheta, M., et al. (2020). Analysis of QTL responsible for grain iron and zinc content in doubled haploid lines of rice (Oryza sativa) derived from an intra-japonica cross. Plant Breed. 139, 344-355. doi: 10.1111/pbr.12787

Johnson, A. A. T., Kyriacou, B., Callahan, D. L., Carruthers, L., Stangoulis, J., Lombi, E., et al. (2011). Constitutive overexpression of the OsNAS gene family reveals single-gene strategies for effective iron and zinc biofortification of rice endosperm. PLoS One 6:e24476. doi: 10.1371/journal.pone.0024476

Jung, H., Lee, D. K., Do Choi, Y., and Kim, J. K. (2015). OsIAA6, a member of the rice Aux/IAA gene family, is involved in drought tolerance and tiller outgrowth. Plant Sci. 236, 304-312. doi: 10.1016/j.plantsci.2015.04.018

Kakei, Y., Ishimaru, Y., Kobayashi, T., Yamakawa, T., Nakanishi, H., and Nishizawa, N. K. (2012). OsYSL16 plays a role in the allocation of iron. Plant Mol. Biol. 79, 583-594. doi: 10.1007/s11103-012-9930-1

Kappara, S., Neelamraju, S., and Ramaman, R. (2018). Donw regulation of a heaby metal transporter gene influences several domestication traita and $\mathrm{Fe}-\mathrm{Zn}$ content in rice. Plant Sci. 276, 208-219. doi: 10.1016/j.plantsci.2018.09.003

Kavitha, P. G., Kuruvilla, S., and Mathew, M. K. (2015). Functional characterization of a transition metal ion transporter, OsZIP6 from rice (Oryza sativa L.). Plant Physiol. Biochem. 97, 165-174. doi: 10.1016/j.plaphy.2015.10.005

Kawakami, K., and Bhullar, N. K. (2018). Molecular processes in iron anHd zinc omeostasis and their modulation for biofortification in rice. J. Integr. Plant Biol. 60, 1181-1198. doi: 10.1111/jipb.12751

Kennedy, G., Nantel, G., and Shetty, P. S. (2003). The scourge of "hidden hunger": global dimensions of micronutrient deficiencies. Food Nutr. Agric. 32, 8-16.

Kim, S. A., Punshon, T., Lanzirotti, A., Li, L., Alonso, J. M., Ecker, J. R., et al. (2006). Localization of iron in Arabidopsis seed requires the vacuolar membrane transporter VIT1. Science 314, 1295-1298. doi: 10.1126/science.1132563

Klatte, M., Schuler, M., Wirtz, M., Fink-Straube, C., Hell, R., and Bauer, P. (2009). The analysis of Arabidopsis nicotianamine synthase mutants reveals functions for nicotianamine in seed iron loading and iron deficiency responses. Plant Physiol. 150, 257-271. doi: 10.1104/pp.109.136374

Kobayashi, T., Nagasaka, S., Senoura, T., Itai, R. N., Nakanishi, H., and Nishizawa, N. K. (2013). Iron-binding haemerythrin RING ubiquitin ligases regulate plant iron responses and accumulation. Nat. Commun. 4:2792. doi: 10.1038/ ncomms 3792

Kobayashi, T., and Nishizawa, N. K. (2012). Iron uptake, translocation, and regulation in higher plants. Annu. Rev. Plant Biol. 63, 131-152. doi: 10.1146/ annurev-arplant-042811-105522

Koike, S., Inoue, H., Mizuno, D., Takahashi, M., Nakanishi, H., Mori, S., et al. (2004). OsYSL2 is a rice metal-nicotianamine transporter that is regulated by iron and expressed in the phloem. Plant J. 39, 415-424. doi: 10.1111/j.1365313X.2004.02146.x

Krohling, C. A., Eutrópio, F. J., Bertolazi, A. A., Dobbss, L. B., Campostrini, E., Dias, T., et al. (2016). Ecophysiology of iron homeostasis in plants. Soil Sci. Plant Nutr. 62, 39-47. doi: 10.1080/00380768.2015.1123116

Kumar, N., Jain, R. R. K., and Chowdhury, V. K. (2019). Linkage mapping of QTLs for grain minerals (iron and zinc) and physio morphological traits for development of mineral rich rice (Oryza sativa L.). Indian J. Biotechnol. 18, 69-80.

Lee, S., and An, G. (2009). Over-expression of OsIRT1 leads to increased iron and zinc accumulations in rice. Plant Cell Environ. 32, 408-416. doi: 10.1111/j.13653040.2009.01935.x

Lee, S., Chiecko, J. C., Kim, S. A., Walker, E. L., Lee, Y., Guerinot, M. L., et al. (2009). Disruption of OsYSL15 leads to iron inefficiency in rice plants. Plant Physiol. 150, 786-800. doi: 10.1104/pp.109.13541

Lee, S., Kim, S. A., Lee, J., Guerinot, M. L., and An, G. (2010). Zinc deficiencyinducible OsZIP8 encodes a plasma membrane-localized zinc transporter in rice. Mol. Cells 29, 551-558. doi: 10.1007/s10059-010-0069-0

Lee, S., Persson, D. P., Hansen, T. H., Husted, S., Schjoerring, J. K., Kim, Y. S., et al. (2011). Bio-available zinc in rice seeds is increased by activation tagging of nicotianamine synthase. Plant Biotechnol. J. 9, 865-873. doi: 10.1111/j.14677652.2011.00606.x

Lee, S.-M., Kang, J.-W., Lee, J.-Y., Seo, J., Shin, D., Cho, J.-H., et al. (2020). QTL analysis for $\mathrm{Fe}$ and $\mathrm{Zn}$ concentrations in rice grains using a 682 doubled haploid population derived from a cross between rice (Oryza sativa) cultivar 93-683 11 and milyang 352. Plant Breed. Biotechnol. 8, 69-76. doi: 10.9787/PBB.2020.8.1. 69

Liu, E., Zeng, S., Zhu, S., Liu, Y., Wu, G., Zhao, K., et al. (2019a). Favorable alleles of GRAIN-FILLING RATE1 increase the grain-filling rate and yield of rice. Plant Physiol. 181, 1207-1222. doi: 10.1104/pp.19.00413

Liu, X. S., Feng, S. J., Zhang, B. Q., Wang, M. Q., Cao, H. W., Rono, J. K., et al. (2019b). OsZIP1 functions as a metal efflux transporter limiting excess 
zinc, copper and cadmium accumulation in rice. BMC Plant Biol. 19:283. doi: 10.1186/s12870-019-1899-3

Lu, K., Li, L., Zheng, X., Zhang, Z., Mou, T., and Hu, Z. (2008). Quantitative trait loci controlling $\mathrm{Cu}, \mathrm{Ca}, \mathrm{Zn}, \mathrm{Mn}$ and $\mathrm{Fe}$ content in rice grains. J. Genet. 87, 305-310. doi: 10.1007/s12041-008-0049-8

Lucena, J. J., and Hernandez-Apaolaza, L. (2017). Iron nutrition in plants: an overview. Plant and Soil 418, 1-4. doi: 10.1007/s11104-017-3316-8

Ludwig, Y., and Slamet-Loedin, I. H. (2019). Genetic Biofortification to Enrich Rice and Wheat Grain Iron:From Genes to Product. Front. Plant Sci. 10:833. doi: $10.3389 /$ fpls.2019.00833

Masuda, H., Kobayashi, T., Ishimaru, Y., Takahashi, M., Aung, M. S., Nakanishi, H., et al. (2013). Iron-biofortification in rice by the introduction of three barley genes participated in mugineic acid biosynthesis with soybean ferritin gene. Front. Plant Sci. 4:132. doi: 10.3389/fpls.2013.00132

Mayer, J. E., Pfeiffer, W. H., and Beyer, P. (2008). Biofortified crops to alleviate micronutrient malnutrition. Curr. Opin. Plant Biol. 11, 166-170. doi: 10.1016/ j.pbi.2008.01.007

Moore, K. L., Chen, Y., Van De Meene, A. M., Hughes, L., Liu, W., Geraki, T., et al. (2014). Combined NanoSIMS and synchrotron X-ray fluorescence reveal distinct cellular and subcellular distribution patterns of trace elements in rice tissues. New Phytol. 201, 104-115. doi: 10.1111/nph. 12497

Moreno-Mayano, L. T., Bonneau, J. P., Sánchez-Palacios, J. T., Tohme, J., and Johnson, A. A. T. (2016). Association of Increased Grain Iron and Zinc Concentrations with Agro-morphological Traits of Biofortified Rice. Front. Plant Sci. 7:1463. doi: 10.3389/fpls.2016.01463

Mu, S., Yamaji, N., Sasaki, A., Luo, L., Du, B., Che, J., et al. (2020). A transporter for delivering zinc to the developing tiller bud and panicle in rice. Plant J. 105, 786-799. doi: 10.1111/tpj.15073

Munns, R., and Tester, M. (2008). Mechanisms of salinity tolerance. Annu. Rev. Plant Biol. 59, 651-681. doi: 10.1146/annurev.arplant.59.032607.09 2911

Murgia, I., Arosio, P., Tarantino, D., and Soave, C. (2012). Biofortification for combating hidden hunger for iron. Trends Plant Sci. 17, 47-55. doi: 10.1016/ j.tplants.2011.10.003

Nagesh, P., Usharani, G., Neeraja, C. N., Babu, V. R., and Reddy, T. D. (2013). Molecular mapping of high iron and zinc rich regions in rice (Oryza sativa L.) grains using microsatellite markers. Helix 2, 231-237.

Norton, G. J., Deacon, C. M., Xiong, L., Huang, S., Meharg, A. A., and Price, A. H. (2010). Genetic mapping of the rice ionome in leaves and grain: identification of QTLs for 17 elements including arsenic, cadmium, iron and selenium. Plant Soil 329, 139-153. doi: 10.1007/s11104-009-0141-8

Nozoye, T. (2018). The Nicotianamine synthase gene is a useful candidate for improving the nutritional qualities and fe-deficiency tolerance of various crops. Front. Plant Sci. 9:340. doi: 10.3389/fpls.2018.00340

Nozoye, T., Nagasaka, S., Kobayashi, T., Takahashi, M., Sato, Y., Sato, Y., et al. (2011). Phytosiderophore efflux transporters are crucial for iron acquisition in graminaceous plants. J. Biol. Chem. 286, 5446-5454. doi: 10.1074/jbc.M110. 180026

Nozoye, T., Von Wirén, N., Sato, Y., Higashiyama, T., Nakanishi, H., and Nishizawa, N. K. (2019). Characterization of the nicotianamine exporter ENA1 in rice. Front. Plant Sci. 10:502. doi: 10.3389/fpls.2019.00502

Paul, S., Ali, N., Swapan, K., Datta, S. K., and Datta, K. (2014). Development of an Iron-enriched High-yieldings indica Rice Cultivar by Introgression of A Highiron Trait from Transgenic Iron-biofortified Rice. Plant Foods Hum. Nutr. 69, 203-208. doi: 10.1007/s11130-014-0431-z

Peris-Peris, C., Serra-Cardona, A., Sánchez-Sanuy, F., Campo, S., Ariño, J., and San Segundo, B. (2017). Two NRAMP6 isoforms function as iron and manganese transporters and contribute to disease resistance in rice. Mol. Plant Microbe Interact. 30, 385-398. doi: 10.1094/mpmi-01-17-0005-r

Pii, Y., Marastoni, L., Springeth, C., Fontanella, M. C., Beone, G. M., Cesco, S., et al. (2016). Modulation of Fe acquisition process by Azospirillum brasilense in cucumber plants. Environ. Exp. Bot. 130, 216-225. doi: 10.1016/j.envexpbot. 2016.06.011

Ramesh, S. A., Shin, R., Eide, D. J., and Schachtman, D. P. (2003). Differential metal selectivity and gene expression of two zinc transporters from rice. Plant Physiol. 133, 126-134. doi: 10.1104/pp.103.026815
Ricachenevsky, F. K., Punshon, T., Lee, S., Oliveira, B. H. N., Trenz, T. S., Maraschin, F. D. S., et al. (2018). Elemental Profiling of Rice FOX Lines leads to characterization of a new Zn plasma membrane transporter, OsZIP7. Front. Plant Sci. 9:865. doi: 10.3389/fpls.2018.00865

Ricachenevsky, F. K., and Sperotto, R. A. (2016). Into the wild: Oryza species as sources for enhanced nutrient accumulation and metal tolerance in rice. Front. Plant Sci. 7:974. doi: 10.3389/fpls.2016.00974

Ricachenevsky, F. K., Sperotto, R. A., Menguer, P. K., Sperb, E. R., Lopes, K. L., and Fett, J. P. (2011). ZINC-INDUCED FACILITATOR-LIKE family in plants: lineage-specific expansion in monocotyledons and conserved genomic and expression features among rice (Oryza sativa) paralogs. BMC Plant Biol. 11:20. doi: 10.1186/1471-2229-11-20

Rodriguez-Celma, J., Connorton, J. M., Kruse, I., Green, R. T., Franceschetti, M., Chen, Y. T., et al. (2019). Arabidopsis BRUTUS-LIKE E3 ligases negatively regulate iron uptake by targeting transcription factor FIT for recycling. Proc. Natl. Acad. Sci. U.S.A. 116, 17584-17591. doi: 10.1073/pnas.1907971116

Rogers, E. E., and Guerinot, M. L. (2002). FRD3, a member of the multidrug and toxin efflux family, controls iron deficiency responses in Arabidopsis. Plant Cell 14, 1787-1799. doi: 10.1105/tpc.001495

Roschzttardtz, H., Seguela-Arnaud, M., Briat, J. F., Vert, G., and Curie, C. (2011). The FRD3 citrate effluxer promotes iron nutrition between symplastically disconnected tissues throughout Arabidopsis development. Plant Cell 23, 27252737. doi: $10.1105 /$ tpc.111.088088

Sasaki, A., Yamaji, N., Xia, J., and Ma, J. F. (2011). OsYSL6 is involved in the detoxification of excess manganese in rice. Plant Physiol. 157, 1832-1840. doi: 10.1104/pp.111.186031

Scagliola, M., Valentinuzzi, F., Mimmo, T., Cesco, S., Crecchio, C., and Pii, Y. (2021). Bioinoculants as promising complement of chemical fertilizers for a more sustainable agricultural practice. Front. Sustain. Food Syst. 4:622169. doi: $10.3389 /$ fsufs. 2020.622169

Senoura, T., Sakashita, E., Kobayashi, T., Takahashi, M., Aung, M. S., Masuda, H., et al. (2017). The iron-chelate transporter OsYSL9 plays a role in iron distribution in developing rice grains. Plant Mol. Biol. 95, 375-387. doi: 10. 1007/s11103-017-0656-y

Shahzad, Z., Rouached, H., and Rakha, A. (2014). Combating Mineral Malnutrition through Iron and Zinc Biofortification of Cereals. Compr. Rev. Food Sci. Food Saf. 13, 329-346. doi: 10.1111/1541-4337.12063

Shou, H., Li, L., Ye, L., and Kong, Q. (2019). A vacuolar membrane ferric-chelate reductase, OsFRO1 alleviates Fe toxicity in rice (Oryza sativa L.). Front. Plant Sci. 10:700. doi: 10.3389/fpls.2019.00700

Sperotto, R. A. (2013). Zn/Fe remobilization from vegetative tissues to rice seeds: Should I stay or should I go? Ask Zn/Fe supply! Front. Plant Sci. 4:464. doi: 10.3389/fpls.2013.00464

Sperotto, R. A., Ricachenevsky, F. K., de Waldow, V. A., and Fett, J. P. (2012). Iron biofortification in rice: It's a long way to the top. Plant Sci. 190, 24-39. doi: 10.1016/j.plantsci.2012.03.004

Sperotto, R. A., Ricachenevsky, F. K., Duarte, G. L., Boff, T., Lopes, K. L., Sperb, E. R., et al. (2009). Identification of up-regulated genes in flag leaves during rice grain filling and characterization of OsNAC5, a new ABA-dependent transcription factor. Planta 230, 985-1002. doi: 10.1007/s00425-009-1000-9

Stangoulis, J. C. R., Huynh, B. L., Welch, R. M., Choi, E. Y., and Graham, R. D. (2007). Quantitative trait loci for phytate in rice grain and their relationship with grain micronutrient content. Euphytica 154, 289-294. doi: 10.1007/ s10681-006-9211-7

Swamy, B. M., Rahman, M. A., Inabangan-Asilo, M. A., Amparado, A., Manito, C., Chadha-Mohanty, P., et al. (2016). Advances in breeding for high grain zinc in rice. Rice 9, 1-16. doi: 10.1186/s12284-016-0122-5

Swamy, B. P. M., Descalsota, G. I. L., Nha, C. T., Amparado, A., Inabangan-Asilo, M. A., Manito, C., et al. (2018a). Identification of genomic regions associated with agronomic and biofortification traits in $\mathrm{DH}$ populations of rice. PLoS One 13:e0201756. doi: 10.1371/journal.pone.0201756

Swamy, B. P. M., Kaladhar, K., Anuradha, K., Batchu, A. K., Longvah, T., and Sarla, N. (2018b). QTL analysis for grain iron and zinc concentrations in two O. nivara derived backcross populations. Rice Sci. 25, 197-207. doi: 10.1016/j.rsci.2018.06. 003

Tan, L., Zhu, Y., Fan, T., Peng, C., Wang, J., Sun, L., et al. (2019). OsZIP7 functions in xylem loading in roots and inter-vascular transfer in nodes to deliver $\mathrm{Zn} / \mathrm{Cd}$ 
to grain in rice. Biochem. Biophys. Res. Commun. 512, 112-118. doi: 10.1016/j. bbrc.2019.03.024

Tian, S., Liang, S., Qiao, K., Wang, F., Zhang, Y., and Chai, T. (2019). Co-expression of multiple heavy metal transporters changes the translocation, accumulation, and potential oxidative stress of $\mathrm{Cd}$ and $\mathrm{Zn}$ in rice (Oryza sativa). J. Hazard. Mater. 380:120853. doi: 10.1016/j.jhazmat.2019.120853

Toxqui, L., and Vaquero, M. P. (2015). Chronic iron deficiency as an emerging risk factor for osteoporosis: a hypothesis. Nutrients 7, 2324-2344. doi: 10.3390/ nu7042324

Trijatmiko, K. R., Dueñas, C., Tsakirpaloglou, N., Torrizo, L., Arines, F. M., Adeva, C., et al. (2016). Biofortified indica rice attains iron and zinc nutrition dietary targets in the field. Sci. Rep. 6:19792. doi: 10.1038/srep19792

Tripathi, D. K., Singh, S., Gaur, S., Singh, S., Yadav, V., Liu, S., et al. (2018). Acquisition and homeostasis of iron in higher plants and their probable role in abiotic stress tolerance. Front. Environ. Sci. 5:86. doi: 10.3389/fenvs.2017. 00086

Uauy, C., Distelfeld, A., Fahima, T., Blechl, A., and Dubcovsky, J. (2006). A NAC Gene regulating senescence improves grain protein, zinc, and iron content in wheat. Science 314, 1298-1301. doi: 10.1126/science.1133649

Van Der Straeten, D., Bhullar, N. K., De Steur, H., Gruissem, W., MacKenzie, D., Pfeiffer, W., et al. (2020). Multiplying the efficiency, and impact of biofortification through metabolic engineering. Nat. Commun. 11:5203. doi: 10.1038/s41467-020-19020-4

Wairich, A., De Oliveira, B. H. N., Arend, E. B., Duarte, G. L., Ponte, L. R., Sperotto, R. A., et al. (2019). The Combined Strategy for iron uptake is not exclusive to domesticated rice (Oryza sativa). Sci. Rep. 9:16144. doi: 10.1038/s41598-01952502-0

Wairich, A., Neves de Oliveira, B. H., Wu, L. B., Murugaiyan, V., MargisPinheiro, M., Fett, J. P., et al. (2020). Chromosomal introgressions from Oryza meridionalis into domesticated rice Oryza sativa result in iron tolerance. J. Exp. Bot. 72, 2242-2259. doi: 10.1093/jxb/eraa461

White, P. J., and Broadley, M. R. (2009). Biofortification of crops with seven mineral elements often lacking in human diets - iron, zinc, copper, calcium, magnesium, selenium and iodine. New Phytol. 182, 49-84. doi: 10.1111/j.14698137.2008.02738.x

Whitt, L., Ricachenevsky, F. K., Ziegler, G. Z., Clemens, S., Walker, E., Maathuis, F. J. M., et al. (2020). A curated list of genes that affect the plant ionome. Plant Direct. 4:e00272.

Wieringa, F. T., Dahl, M., Chamnan, C., Poirot, E., Kuong, K., Sophonneary, P., et al. (2016). The high prevalence of anemia in Cambodian children and women cannot be satisfactorily explained by nutritional deficiencies or hemoglobin disorders. Nutrients 8:348. doi: 10.3390/nu8060348

World Health Organization (2002). Reducing Risks, Promoting Healthy Life. Available online at: https://www.who.int/whr/2002/en/summary_riskfactors_ chp4.pdf (accessed December 16, 2019).

World Health Organization (2008). Worldwide Prevalence of Anaemia 1993-2005: WHO Global Database on Anaemia. Switzerland: WHO Press.

World Health Organization (2015). The Global Prevalence of Anemia in 2011. Available online at: https://apps.who.int/iris/ bitstream/handle/10665/177094/9789241564960_eng.pdf;jsessionid= 696FEA50075C541C33AF6CC06F83A91D?sequence=1 (accessed December 16, 2019).

Xiong, H., Kakei, Y., Kobayashi, T., Guo, X., Nakazono, M., Takahashi, H., et al. (2013). Molecular evidence for phytosiderophore-induced improvement of iron nutrition of peanut intercropped with maize in calcareous soil. Plant Cell Environ. 36, 1888-1902. doi: 10.1111/pce.12097

Xu, Q., Zheng, T. Q., Hu, X., Cheng, L. R., Xu, J. L., Shi, Y. M., et al. (2015). Examining two sets of introgression lines in rice (Oryza sativa L.) reveals favorable alleles that improve grain $\mathrm{Zn}$ and $\mathrm{Fe}$ concentrations. PLoS One 10:e0131846. doi: 10.1371/journal.pone.0131846

Yamaji, N., and Ma, J. F. (2014). The node, a hub for mineral nutrient distribution in graminaceous plants. Trends Plant Sci. 19, 556-563. doi: 10.1016/j.tplants. 2014.05.007

Yamaji, N., and Ma, J. F. (2017). Node-controlled allocation of mineral elements in Poaceae. Curr. Opin. Plant Biol. 39, 18-24. doi: 10.1016/j.pbi.2017.05.002

Yamaji, N., and Ma, J. F. (2019). Bioimaging of multiple elements by highresolution LA-ICP-MS reveals altered distribution of mineral elements in the nodes of rice mutants. Plant J. 99, 1254-1263. doi: 10.1111/tpj.14410

Yokosho, K., Yamaji, N., and Ma, J. F. (2016). OsFRDL1 expressed in nodes is required for distribution of iron to grains in rice. J. Exp. Bot. 67, 5485-5494. doi: 10.1093/jxb/erw314

Yokosho, K., Yamaji, N., Ueno, D., Mitani, N., and Ma, J. F. (2009). OsFRDL1 is a citrate transporter required for efficient translocation of iron in rice. Plant Physiol. 149, 297-305. doi: 10.1104/pp.108.128132

Zhang, C., Lu, W., Yang, Y., Shen, Z., Ma, J. F., and Zheng, L. (2018a). OsYSL16 is required for preferential $\mathrm{Cu}$ distribution to floral organs in rice. Plant Cell Physiol. 59, 2039-2051. doi: 10.1093/pcp/pcy124

Zhang, C., Shinwari, K. I., Luo, L., and Zheng, L. (2018b). OsYSL13 Is Involved in Iron Distribution in Rice. Int. J. Mol. Sci. 19:3537. doi: 10.3390/ijms1911 3537

Zhang, M., Pinson, S. R. M., Tarpley, L., Huang, X. Y., Lahner, B., Yakubova, E., et al. (2014). Mapping and validation of quantitative trait loci associated with concentrations of 16 elements in unmilled rice grain. Theor. Appl. Genet. 127, 137-165. doi: 10.1007/s00122-013-2207-5

Zhang, X., Chen, Y., Lin, X., Hong, X., Zhu, Y., Li, W., et al. (2013). Adenine phosphoribosyl transferase 1 is a key enzyme catalyzing cytokinin conversion from nucleobases to nucleotides in Arabidopsis. Mol. Plant 6, 1661-1672. doi: $10.1093 / \mathrm{mp} / \mathrm{sst} 071$

Zhang, Y., Xu, Y. H., Yi, H. Y., and Gong, J. M. (2012). Vacuolar membrane transporters OsVIT1 and OsVIT2 modulate iron translocation between flag leaves and seeds in rice. Plant J. 72, 400-410. doi: 10.1111/j.1365-313X.2012. 05088.x

Zheng, L., Yamaji, N., Yokosho, K., and Ma, J. F. (2012). YSL16 is a phloemlocalized transporter of the copper-nicotianamine complex that is responsible for copper distribution in rice. Plant Cell 24, 3767-3782. doi: 10.1105/tpc.112. 103820

Conflict of Interest: The authors declare that the research was conducted in the absence of any commercial or financial relationships that could be construed as a potential conflict of interest.

Copyright (C) 2021 Swamy, Marathi, Ribeiro-Barros, Calayugan and Ricachenevsky. This is an open-access article distributed under the terms of the Creative Commons Attribution License (CC BY). The use, distribution or reproduction in other forums is permitted, provided the original author(s) and the copyright owner(s) are credited and that the original publication in this journal is cited, in accordance with accepted academic practice. No use, distribution or reproduction is permitted which does not comply with these terms. 